\title{
An Intersubjective Analysis of Engineering Leadership Across Organizational Locations: Implications for Higher Education
}

Cindy Rottmann, Douglas W. Reeve, Robin Sacks, and Mike Klassen University of Toronto

\begin{abstract}
Engineering leadership education has become increasingly popular over the past decade in response to national calls for educational change. Despite the growing popularity of the movement, however, reform efforts continue to be piecemeal in their delivery, driven largely by the priorities of program leaders who established them (Graham, 2012). If we as engineering educators wish to more systematically develop leadership skills in our students, we should begin by empirically examining and defining our phenomenon of interest: engineering leadership. Our article takes up this challenge by investigating how 82 engineers in five organizationally distinct roles define leadership and how their respective insights are shaped by their diverse organizational locations. After weaving together the perspectives of engineers in industry, human resource professionals, entrepreneurs, politicians and interns, we propose a poly-vocal definition of engineering leadership and identify practical implications for engineering leadership educators.

\section{Résumé}

En réponse aux appels à réformer le système de l'éducation, la formation de leaders en génie a gagné en popularité au cours des dix dernières années. Malgré la popularité croissante de ce mouvement, les réformes demeurent partiales et suivent largement les priorités des directeurs de programmes qui les mettent en place (Graham, 2012). Si, en tant que formateurs d'ingénieurs, nous souhaitons perfectionner systématiquement les compétences en leadership de nos étudiants, il nous faut commencer par une analyse empirique
\end{abstract}


qui permette de définir précisément notre objet, soit le leadership en génie. Notre article relève le défi en analysant les façons dont 82 ingénieurs occupant cinq rôles distincts dans une organisation définissent le leadership, et les façons dont leurs positions institutionnelles établissent leurs perspectives. En tenant compte des perspectives d'ingénieurs de l'industrie, de professionnels des ressources humaines, d'entrepreneurs, de politiciens et de stagiaires, nous proposons une définition plurivoque du leadership en génie, et nous en identifions les implications pratiques pour les éducateurs du domaine.

\section{Introduction}

In 2004, the US-based National Academy of Engineering published The Engineer of $202 O$ - a call for reform, encouraging engineering faculties in the United States to supplement technical skills instruction with professional, social, and organizational skills development opportunities for their students. Central to this call was the argument that a more balanced curriculum would enhance engineers' abilities to take on leadership roles in business, non-profit, academic, and government sectors, thereby accelerating the economic productivity of the nation and enhancing its citizens' quality of life. In 2009, Engineers Canada issued a similar call for reform, urging faculties of engineering to prepare students for leadership roles in Canadian society. Reform efforts in both countries have been assessed through national accreditation boards, the Accreditation Board for Engineering and Technology (ABET) in the United States and the Canadian Engineering Accreditation Board (CEAB) in Canada.

Since the mid-200os, many have echoed these national calls for reform, using two distinct but complementary rationales. The first line of thinking suggests that engineers who supplement their technical training with leadership education will be well positioned to compete in the increasingly global marketplace (Doboli et al., 2010; Engineers Canada, 2009; Flowers, 2002; Katehi, 2005; National Academy of Engineering, 2004, 2005, 2012; Ulsoy, 2005; Vest, 2005, 2011). The second rationale for engineering educational reform is that leadership education helps engineers fulfil their professional service responsibilities to society (Baranowski, 2011; Bonasso, 2001; Cassin, 2003; Emison, 2011; Grasso \& Martinelli, 2007; Mawson, 2001; Pierson, 2013; Reeve, 2010; Reeve, Sacks, \& Rottmann, 2014; Reeve, Simpson, \& Evans, 2010; Roncin, 2013). In both cases, whether the driving force has been competition or service, the proposed solution is the same: engineering educators must supplement technical coursework with interpersonal program elements if they wish to prepare their students for personal success and professional impact. Faculty members, instructors, and industry partners have used a wide range of instructional strategies and program structures to engage engineers in leadership education and to assess students' development as leaders, but according to Ruth Graham (2012) these initiatives remain "piecemeal" in their delivery, driven largely by the priorities of program leaders who established them. If we as engineering educators wish to more coherently or systematically develop our students into leaders, we should begin by defining what engineering leadership means. Our paper takes on this challenge by examining how five differently positioned occupational groups-professional engineers working in industry, human resource professionals working with engineers, engineering entrepreneurs, 
elected politicians with engineering credentials, and senior undergraduate students with industry experience as interns-characterize engineering leadership in their respective organizational contexts. After reviewing the engineering leadership literature, we synthesize the perspectives of these five groups of engineers and identify implications for leadership educators in engineering and other professional faculties.

\section{What Does the Literature Say About Engineering Leadership?}

Professional engineers have occupied a range of management positions and taken on many leadership responsibilities over the years, but the topic of engineering leadership has only recently become a legitimate field of academic inquiry. More often than not, it has been located within the larger, more established body of knowledge on engineering education. While still in its infancy, the engineering leadership literature can be broken down into five streams: calls for engineers to take on leadership roles, engineering leadership program descriptions, competency-based depictions of effective engineering leaders, empirical studies of engineering leadership in industry, and conceptual examinations of leadership from an engineering perspective. All five streams are linked to the education of undergraduate engineers: the first through national policy channels, the second as evidence of implementation in higher education, the third as a foundation for academic accreditation, the fourth as a needs assessment for post-graduate professional development, and the fifth as a preliminary conceptual examination of engineering leadership from the perspective of professional insiders. We briefly review these five streams of literature below to contextualize our findings.

\section{Calls for Engineering Leadership}

Engineers and engineering educators have highlighted at least three reasons for their colleagues and students to embrace leadership. At the most practical level, Bergeron (2001) and Kirschenman (2011) note that nearly all engineers in industry are faced with management challenges from time to time, so it is incumbent upon them to learn how to lead. At an equally practical but more global level, Katehi (2005) argues that engineers need to be prepared for the leadership responsibilities inherent in an increasingly globalized economy. Finally, the most widespread and compelling rationale for engineers to stand up and count themselves as leaders is to ensure that their service potential to society is fully realized (Bonasso, 2001; Cassin, 2003; Engineers Canada, 2009; Flowers, 2002; Mawson, 2001; National Academy of Engineering, 2004; Pierson, 2013; Reeve, 2010). Each of these calls for engineering leadership speaks to different audiences: the first to professional engineers in industry; the second to national, state, and provincial policy makers in higher education; and the third to engineers' professional associations and regulatory bodies.

\section{Engineering Leadership Education Initiatives}

There is widespread evidence that this call for reform has been heard within the higher education sector, as engineering leadership program descriptions are the most prevalent type of literature on engineering leadership. While a few researchers have conducted program evaluations across institutional contexts (Froyd, 2005; Graham, 2012; Graham, 
Crawley, \& Mendelsohn, 2009), most articles constitute non-empirical descriptions of programmatic and curricular initiatives. The three most prominent foci of engineering leadership programs depicted in the literature are entrepreneurship and innovation (Hsiao, 2013; Soundarajan, Ramnath, \& Weide, 2013; Stewart, 2005), personal and professional growth (Colcleugh \& Reeve, 2013; McCuen, 1999; Reeve et al., 2010; Simpson, Evans, \& Reeve, 2010), and global citizenship (Athreya et al., 2010; Ellis \& Petersen, 2011; McMartin, 2013). The first two involve skill building and industry partnerships, while the third concentrates on international mobility and service learning projects in the global south. Faculty members, instructors, and industry partners have used a wide range of instructional strategies to engage engineers in leadership education and to assess students' development as leaders, including direct instruction of leadership skills and traits (Bayless, 2013; Passow, 2012; Pitts, Klosterman, \& McGonagle, 2013; Riley, Horman, \& Messner, 2008), problem-based learning (Cain \& Cocco, 2013), case studies (Falkenburg, 2005; Gheorghe, Hodgson, \& Van der Loos, 2013; Kerns, Miller, \& Kerns, 2005; Loui, 2005), grand challenges curricula (Kalonji, 2005), reverse engineering (Foster \& Sheridan, 2013), experiential education (Osagiede, Farmer Cox, \& Ahn, 2013; Simpson et al., 2010), formative peer assessment (Sheridan, Reeve, \& Evans, 2012), capstone projects (Bishop, 2013), and team effectiveness inventories (Evans et al., 2013; Sheridan, Evans, \& Reeve, 2012; Sheridan, Reeve, \& Evans, 2014). The extent to which these strategies support the development of effective engineering leaders has not yet been determined, but the wide range of foci, program structures, institutional locations, and instructional strategies developed by engineering educators has certainly diversified the curricular and cocurricular offerings in many North American faculties of engineering.

\section{Skills and Traits of Effective Leaders}

A third stream of engineering leadership literature comprises competency-based depictions of effective leaders communicated to an audience of engineers. Farr and his colleagues were the first to identify leadership qualities relevant to engineers. These qualities include big thinker, ethical and courageous, master of change, risk taker, mission that matters, decision maker, uses power wisely, team builder, and good communicator (Farr \& Brazil, 2009; Farr, Walesh, \& Forsythe, 1997). Nearly a decade later, Goodale (2005) proposed a list of leadership skills (visionary, problem solving, team building, management, communication, mentoring, and delegation) and traits (honesty, sincerity, courage, pride, adaptability, influence, and competence) generated in a business context but deemed by the author to be applicable to engineers. These two sets of attributes may be linked to effective leadership, but it is not clear how the authors have methodologically arrived at their lists or how they have factored engineering into their research. The remaining two examples were developed by engineers, with engineers in mind. Ivey (2005) proposed five qualities of engineering leaders relevant to the construction industry-integration, innovation, separation of important from trivial matters, intensity, and integrity-while Pitts and his colleagues (2013) identified 14 leadership capabilities deemed to be important by industry partners of an intensive engineering leadership program: initiative, decision making, responsibility and urgency to deliver, resourcefulness, ethical actions and integrity, trust and loyalty, courage, vision, realizing the vision, inquiry, interpersonal skills, communicating and advocacy, connecting, negotiating, and compromise. Six of the twenty-five leadership 
Inter-subjective analysis of Engineering Leadership/ C. Rottmann, D. W. Reeve, R. Sacks, \& M. Klassen 150

attributes appear in at least three of the four lists: generating or realizing a vision, courageous risk taking, change agency or adaptability, decision making, team building, and ethical behaviour or integrity. The overlapping attributes are clearly tied to leadership, but there is little evidence to assess their unique relevance to engineers.

\section{Empirical Studies of Engineering Leadership in Industry}

The fourth stream of literature investigates engineering leadership in a range of industry contexts using analytical rather than purely descriptive research methods. Three studies are cross-case comparisons of "best practices" (Hensey, 2001; Kenner \& Isaak, 2004; Shane, Strong, \& Gransberg, 2011), two rely on quantitative data drawn from quasi-experimental designs (Martines-Corcoles, Gracia, Tomas, Peiro, \& Schobel, 2013; Skipper \& Lansford, 2008), three use traditional leadership theories to assess the effectiveness of engineers in leadership roles (Ning, Zhou, Lu, \& Wen, 2012; Singh \& Jampel, 2011; Zhou \& Liu, 2011), and three mix survey results with thematic analyses of interview transcripts to examine engineering leadership in the construction industry (Toor, 2011; Toor \& Ofori, 2011; Toor \& Ogunlana, 2009). The organizationally contextualized nature of these studies blends the promising leadership aspirations present in the first three streams of literature with a range of engineering workplace realities. Still, in many cases, the authors use conceptions of leadership arising from the management literature as a standard against which to measure engineers. In the case of Singh and Jampel's study, this standardized approach resulted in a negative assessment of engineering leaders as predominantly "laissez-faire" in their approach. While it is possible that engineers truly approach leadership with a laissez-faire attitude, it is also possible that their professional respect for the autonomy and creativity of their internally motivated team members was incorrectly read as "hands off" rather than impactful or trusting.

\section{What Is Engineering Leadership?}

The final stream of engineering leadership literature includes the fewest publications, but it is most directly relevant to our study. Rather than applying leadership standards from other disciplines to engineers, these four teams of researchers examine leadership from an engineering perspective. Mallette (2005) draws on 30 years in the aerospace industry to construct a leadership style best suited to the management of engineers. He calls this style "Theory Pi" and contrasts it with "Theory X" and "Theory Y," loosely based on transformational and transactional leadership. Theory Pi is built on Mallette's conception of engineers as individuals who are motivated by tasks, respond well to hands-off leaders with expert technical knowledge, resolve conflicts through logical reasoning, and expect their job performance to be based primarily on the quality of their final products. Mallette's article reads more like a set of recommendations for managers of engineers than a theory of engineering leadership, but his reference to the popularity of hands-off managers does shed light on Singh and Jampel's (2011) findings that engineers are often characterized as laissez-faire leaders. Robledo, Peterson, and Mumford (2012) similarly take the work of engineers seriously in their three-vector model of creative leadership, which integrates Mumford and his colleagues' five stages of creative projects-scanning, elaboration, development, appraisal, and implementation (Mumford, Scott, Gaddis, \& 
Strange, 2002)-into a flow chart based on three key vectors along which engineers and scientists exercise influence: the group, the work, and the organization. Their model is procedurally dense but conceptually weak, in that it fails to define engineering leadership. Ahn, Cox, London, Cekic, and Zhu (2014) begin to fill in this conceptual gap by identifying five leadership categories generated by thematically coding interviews with 23 engineers. Their five categories-people, society, organization, competency, and money-provide a useful set of engineering leadership domains, but the resulting framework has not been adequately fleshed out using illustrative quotations. Finally, Rottmann, Sacks, and Reeve (2015) use focus group and interview-based data with engineers in industry to identify three orientations to engineering leadership: technical mastery, collaborative optimization, and organizational innovation. While Rottmann et al.'s grounded theory conceptualizes leadership from the perspective of engineers, it fails to connect engineers' varied roles and perspectives to their corresponding definitions of engineering leadership. What do engineers with different sets of responsibilities mean when they talk about leadership? Where does each of them stand in relation to the phenomenon of engineering leadership? How can researchers synthesize multiple perspectives on engineering leadership without losing any voices or ignoring salient contextual features? Our paper responds to these questions and adds to the ongoing conversation about educational improvement in undergraduate faculties of engineering by analyzing how five differently located occupational subgroups of engineers define leadership. In particular, our paper investigates the following research questions:

1. How do engineers in different roles define leadership?

2. How do their organizational locations shape their insights?

\section{Theoretical Perspective}

The questions that drive our research draw on an interpretivist paradigm, which is based on the assumption that differently located actors intersubjectively construct social reality (Denzin, 2002; Schutz, 1967). Our relativist ontology leads us to take the experiences of differently positioned actors seriously in the search for a multivocal "truth," and our subjectivist epistemology presumes that people cannot separate themselves from what they know. Thus, as interpretivists, we believe that the perspectives of actors are located in a particular biographical, organizational, and social context that cannot meaningfully be disconnected from their interpretations of social phenomena.

This theoretical perspective can be illustrated through a famous parable drawn from Hindu, Sufi, Jain, and Buddhist traditions. Briefly, each of six blind men encounters a different part of an elephant and generalizes his specific experience to the whole animal. The man who touches the animal's tail, for example, believes elephants are ropelike creatures, while the man who touches the animal's belly believes elephants are like walls. Their initially irreconcilable perspectives come together when they are prompted to acknowledge each other's realities. As we understand it, the story illustrates the multidimensional nature of truth and the rich possibility of reconciling diverse perspectives through exploratory inquiry and dialogue.

Like the elephant in the parable, the idea of "leadership" is "inter-subjectively available" (Schutz, 1967) to many people. That is, it holds meaning and is thus apprehensible to many individuals despite the fact that it takes different shapes in the minds of different 
actors. Like the men surrounding the elephant, engineers in different roles have access to leadership. The five occupational subgroups of engineers we interviewed were not physically standing around a tangible manifestation of leadership, but they did have access to different organizational structures, actors, processes, and sources of information about our phenomenon of interest. We use the term "organizational location" to institutionally contextualize their perspectives. In particular, we record where they work, the people with whom they interact, and the aspects of organizational life to which they have access, then link these contextual cues to their varied definitions of leadership. We are not arguing that leadership opportunities are limited to engineers in particular hierarchically defined positions (such as chief executive officers or regional directors), but we are suggesting that engineers' varied understandings of leadership are shaped by their organizationally mediated experiences and that engineering students with leadership aspirations should be exposed to all five of these perspectives.

The parable of the blind men and the elephant is a useful but limited metaphor. Unlike the object of study in the parable, social phenomena like leadership have no concrete reality independent of our understanding of them. It is the combination of all actors' experiences that allows us to gain insights about our phenomenon of interest. Engineers working in industry will experience something different about our elephant than will human resource professionals, engineering students, or politicians with engineering training. Their interpretations differ because their varied experiences expose them to a diversity of truths about leadership. To the extent that we record all of these truths and account for the contexts from which they have been drawn, we will be better equipped as engineering educators to prepare our students for a wide range of leadership roles and responsibilities.

\section{Methodology}

This paper is part of a larger mixed methods study on engineering leadership. Our analysis of qualitative data from seven focus groups with 45 engineers allowed us to generate a preliminary grounded theory of engineering leadership (Reeve, Sacks, Rottmann, Daniels, \& Wray, 2013; Rottmann et al., 2015), which we then pilot-tested using a factor analysis of survey data from 200 engineers. Our survey allowed us not only to test our theory but also to examine the top skills and traits of engineers identified as exemplary leaders by their colleagues (Reeve, Rottmann, \& Sacks, 2015). Our current line of inquiry contextualizes our earlier findings by examining how engineers in different roles define engineering leadership and how their organizational locations shape their insights.

After securing institutional ethical approval, we used a combination of purposive and convenience sampling to identify study participants (Miles \& Huberman, 1994). We generated a list of engineering-intensive firms in a $100-\mathrm{km}$ radius from the university and assigned a point value to each organization for our three purposive criteria: engineering concentration, commitment to leadership development, and a cross-section of engineering disciplines. Our rationale for including the first two criteria was that we believed individuals working for engineering-intensive firms with formal leadership programing would have the most experience with our phenomenon of interest-engineering leadership. We included the third criterion to account for the high degree of disciplinary diversity within engineering. High-investment, high-risk industries like mining and energy have different accountability and leadership structures than high-innovation, low-risk industries like 
Inter-subjective analysis of Engineering Leadership/ C. Rottmann, D. W. Reeve, R. Sacks, \& M. Klassen 153

software engineering. Four organizations in four industry sectors-chemical, consulting, software, and mining-met our criteria and consented to participate in the study. Please see Table 1 for the organizational characteristics of our sample.

Table 1.

Sample Size, Organizational Context, and Data Collection Strategies (N=82)

\begin{tabular}{|c|c|c|c|c|}
\hline Role & Industry & Organizational size \& type & $\begin{array}{l}\text { Data } \\
\text { collection }\end{array}$ & $\begin{array}{l}\text { Number of par- } \\
\text { ticipants (sex) }\end{array}$ \\
\hline $\begin{array}{l}\text { Engineers in } \\
\text { industry } \\
(\mathrm{N}=45: \\
31 \mathrm{M} / 14 \mathrm{~F})\end{array}$ & $\begin{array}{l}\text { Chemical } \\
\text { Consulting } \\
\text { Software } \\
\text { Mining }\end{array}$ & $\begin{array}{l}\text { Small, flat, departmental } \\
\text { Large, flat, departmental } \\
\text { Small, flat, project teams } \\
\text { Large, hierarchical }\end{array}$ & $\begin{array}{l}1 \text { focus group } \\
2 \text { focus groups } \\
2 \text { focus groups } \\
1 \text { focus group }\end{array}$ & $\begin{array}{l}9(6 \mathrm{M}, 3 \mathrm{~F}) \\
17(1 \mathrm{OM}, 7 \mathrm{~F}) \\
10(9 \mathrm{M}, 1 \mathrm{~F}) \\
9(6 \mathrm{M}, 3 \mathrm{~F})\end{array}$ \\
\hline $\begin{array}{l}\text { Human re- } \\
\text { source pro- } \\
\text { fessionals \& } \\
\text { educators } \\
(\mathrm{N}=7: 2 \mathrm{M} / 5 \mathrm{~F})\end{array}$ & $\begin{array}{l}\text { Chemical } \\
\text { Consulting } \\
\text { Software } \\
\text { Mining }\end{array}$ & $\begin{array}{l}\text { Small, flat, departmental } \\
\text { Large, flat, departmental } \\
\text { Small, flat, project teams } \\
\text { Large, hierarchical }\end{array}$ & $\begin{array}{l}1 \text { interview } \\
1 \text { interview } \\
1 \text { interview } \\
1 \text { interview }\end{array}$ & $\begin{array}{l}1(\mathrm{~F}) \\
2(2 \mathrm{~F}) \\
2(1 \mathrm{M}, 1 \mathrm{~F}) \\
2(1 \mathrm{M} 1 \mathrm{~F})\end{array}$ \\
\hline $\begin{array}{l}\text { Engineer- en- } \\
\text { trepreneurs } \\
(\mathrm{N}=6: 6 \mathrm{M})\end{array}$ & $\begin{array}{l}\text { Finance (x2), } \\
\text { Software (x2), } \\
\text { Energy \& } \\
\text { Electrical (x2) }\end{array}$ & $\begin{array}{l}\text { Small start-ups that grew } \\
\text { or } \\
\text { were acquired by larger } \\
\text { organizations }\end{array}$ & 1 focus group & $6(6 M)$ \\
\hline $\begin{array}{l}\text { Engineer- } \\
\text { politicians } \\
(\mathrm{N}=2: 2 \mathrm{M})\end{array}$ & Government & $\begin{array}{l}\text { Local representatives of } \\
\text { federal parties (members } \\
\text { of Parliament) }\end{array}$ & 2 interviews & $2(2 M)$ \\
\hline $\begin{array}{l}\text { Interns } \\
(\mathrm{N}=22: \\
16 \mathrm{M} / 6 \mathrm{~F})\end{array}$ & Education & $\begin{array}{l}\text { Large, research-intensive } \\
\text { university }\end{array}$ & 2 focus groups & $22(16 \mathrm{M}, 6 \mathrm{~F})$ \\
\hline
\end{tabular}

We conducted six focus groups with junior and senior engineers at our four partner organizations and one semi-structured interview with human resource professionals from each company to learn more about the relationship between engineering leadership and organizational context. After learning that a critical mass of engineers in our sample resisted the idea of engineering as a leadership profession, we searched for a counter narrative by interviewing two groups of engineers who self-identified as leaders: entrepreneurs and politicians. We conducted a focus group with six engineering entrepreneurs and two semi structured interviews with Canadian politicians known to have engineering training and industry experience. Finally, our attempts to improve engineering leadership education would have been incomplete without the perspectives of students undergoing school-to-work transitions. We ran two additional focus groups with senior engineering students who had elected to complete a 16-month internship following their third year of undergraduate studies. In total, we conducted nine focus groups and six interviews with 82 respondents: 45 engineers working for four engineering-intensive organizations, 22 
engineering students with industry experience, seven human resource professionals, six engineering entrepreneurs, and two engineers elected to federal politics. All of the entrepreneurs and politicians were male. The majority of the engineers in industry and interns were also male. Most of the human resource professionals were female. Overall, our sample was 70\% male and 30\% female, which loosely reflects the percentage of women in some of the more gender-balanced engineering industries including chemical, industrial, and civil-two of which are heavily represented in our sample.

We audio-recorded and transcribed 166 hours of interview and focus group data, which we then analyzed inductively (Denzin, 2002; Denzin \& Lincoln, 2003) using the constant comparison method (Glaser, 1965; Glaser \& Strauss, 1967). After analyzing each transcript separately, we identified patterns between and within participant subgroups, paying particular attention to the relationships between participants' organizational locations and their conceptions of engineering leadership. Our findings are presented as five narrative layers. When woven together, these layers form a comprehensive definition of engineering leadership reflecting the perspectives of engineers in industry, human resource professionals, engineering entrepreneurs, politicians with engineering experience, and engineering students.

\section{Findings}

Engineers and the people who work with them conceptualize leadership in a variety of ways, based partly on their distinct roles, specialized functions, and resulting access to information. Our analysis of qualitative interviews with 82 participants suggests that these distinct sets of experiences lead to useful, organizationally specific insights, all of which are relevant to engineering leadership educators. We present our findings as five occupationally contextualized narratives about engineering leadership.

\section{Engineers in Industry: Engineering Is Not a Leadership Profession but It Is Possible to Characterize Three Professional Exemplars}

When we began conducting focus groups with engineers working in traditional engineering industries, we were surprised to find strong resistance to the idea of engineers as leaders. The majority of participants in our first few focus groups were working on technical project teams as engineers in training, technical specialists, or team leaders. They had professional relationships with colleagues working on the same project, team leaders, specialists within their departments, and suppliers, but they had limited access to senior leadership structures, board meetings, human resource procedures, strategic planning, and other organizational policy-making processes. For these engineers, whether they were working in large, hierarchical firms or smaller, flatter organizations, "leadership" was a suspect term. Many engineers in these focus groups found the idea of leadership to be imprecise, impractical, elitist, and just "not us" (Reeve et al., 2013; Rottmann et al., 2015):

The connotation that the word "leadership" carries is sort of antithetical to the engineering mindset from my point of view. For example, the notion of standing on top of a hill, waving the flag, sitting on your horse with the peasants behind you carrying their [pitch] forks is the exact opposite of anything I personally or anyone I know wants to do. 
When we probed a little deeper, we found that participants' resistance emerged from perceived disparities between their strongly held professional identities and their somewhat traditional perspectives on leadership. Interestingly, when we shifted our interviewing language from "leadership" to "influence," we found that the engineers in our first set of focus groups had no difficulty identifying exemplary models of professional excellence. They were still averse to the classification of engineering as a leadership profession, but almost all of them could identify colleagues who "led by example." Engineers who excelled at professionally relevant skills such as technical problem solving, process optimization, and innovative design were held in high regard, particularly when these skills were combined with strong communication, team facilitation, and strategic planning abilities. When we analyzed participants' characterizations of successful colleagues, three distinct engineering leadership orientations emerged: technical mastery, collaborative optimization, and organizational innovation (Reeve et al., 2013; Rottmann et al., 2015). When we surveyed a larger sample of engineers, we found that most participants recognized themselves and their colleagues in one or more of these orientations (Reeve et al., 2015).

Technical mastery involved problem-solving expertise passed on through informal advice, coaching, and mentorship. Typically, individuals with this leadership orientation were identified as the "go-to" specialists in their field.

Leadership is often implicit and you will be implicitly chosen by your peers. ... In a team, you are going to have somebody who just kind of emerges. The real leader, where the rubber meets the road is your tech lead.

Engineers with a collaborative optimization orientation to leadership were recognized as skilled facilitators of team process with an eye to quality, efficiency, motivation, and engagement.

If you throw me in one of these systems, I am not going to become the leader of the pack, but I am going to make it work better. . . . What happens to me personally is that I get thrown into more and more exciting packs. It's like they know whenever I am in one of these groups, I make it work better.

Finally, engineers with an organizational innovation orientation to leadership engaged in outside-the-box thinking and visionary realization of practical, entrepreneurial, and intrapreneurial ideas.

Colleagues who I perceive as effective often have a broader picture of what is going on, so they know they are solving the right problem as opposed to just doing the best job solving this problem.

Together, these three engineering leadership orientations emphasize the importance of influencing one's peers through professional competence-in other words, leading by example. Engineers who continually demonstrate key professional competencies embody leadership for colleagues whose day-to-day experiences occur primarily at the project team level in engineering-intensive industries. 


\section{Human Resource Professionals: The Importance of Organizational Fit}

Human resource professionals working in engineering-intensive organizations tended to be located in central management offices without possessing the decision-making authority of senior engineering leaders. They had a bird's-eye view of hiring and promotion policies, organizational vision statements, and onboarding challenges faced by newly hired engineers, but they had limited access to technical team processes and strategic planning. While many of these individuals came to their positions with engineering degrees, their primary role involved educating new engineers about organizational expectations and professional conduct. In fact, in all four of our partner organizations, at least one of the human resource professionals we interviewed was responsible for structuring professional development opportunities for newly hired engineers and junior engineers undergoing career transitions. As such, their insights moved beyond hiring and promotion to training and organizational socialization. Their work catalyzing the leadership transitions of engineers indicated to us that they were open to the idea of engineering leadership, but they tended to respond to our questions about leadership by discussing organizational fit:

A good fit is somebody who can quickly fit into the culture of the organization and take on the work that needs to be done. We are looking for people who are fast on the uptake, quick to learn, and adaptable to the multiple settings and multiple people they have to work with.

Human resource professionals observed that engineers who made a point of examining their organizational context not only had an easier time fitting in but were also better able to manage their expectations for career advancement because they knew that being assigned projects with increasing scope, size, and complexity was the engineering equivalent to vertical promotion in more hierarchical professions:

There isn't a lot of vertical movement in this organization. It is more that the scope and size of the projects change. So engineers' progression would be that they are part of a team, they move into leading teams and taking on projects where they are working with a whole range of people.... There are very few positions for them to move up to. [Leadership and advancement] are about scope and complexity.

As project scope and complexity increased in all four organizations, so did engineers' requirements to supplement their technical skills with social skills:

Engineers tend to think in black and white, that equations should drive their solutions, but often there are shades of grey. ... Everything we operate involves people. ... You need to be able to listen to people, to hear their thoughts and hear their concerns and hear their opinions. That is what great engineers look like. If someone is stubborn, not listening, opinionated, and not open to suggestions, they might not be a good example of a leader.

Since human resource professionals had learned through experience that employees with poor social skills were an organizational liability, they attempted to be proactive with senior leadership by suggesting that new hires be selected, in part, on the basis of their interpersonal skills: 
Some of the senior engineers used to be highly focused on technical skills only during interviews because they thought the rest would take care of itself, but I think our experience really is demonstrating that the rest doesn't take care of itself. Where we get into challenges, even with experienced engineers, is that those who lack group or consulting skills may have a very good solution, but they cannot get buy-in from the team, the plant, head office, or the client. Without this buy-in, they cannot lead.

The human resource professionals and educators we interviewed defined engineering leadership as the optimization of organizational fit between adaptable, socially competent problem solvers and the pre-existing needs of their respective firms. To frame this in a more agentic way, they believed that engineers who aligned their technical contributions with organizational needs, worked well with others, and balanced their expectations of career advancement with existing organizational realities were optimal leadership candidates. In terms of their own leadership efforts within engineering-intensive organizations, all seven human resource professionals spoke about their attempts to integrate interpersonal skill criteria into their employers' hiring and promotion practices.

\section{Entrepreneurs: Engineers Have a Responsibility to Lead}

The six engineers in our entrepreneur focus group were either chief executive officers of organizations that began as small, innovative start-ups or directors of former start-ups that had been acquired by larger firms. In all cases, they were in formal leadership positions at or near the top of their respective organizational hierarchies, so it did not surprise us that all six of them self-identified as leaders. Their experiences shepherding innovative technologies through to marketable solutions taught them that engineers must be leaders if they wish to experience professional success and maximize their impact. As such, our initial finding that many engineers resisted the idea of leadership surprised and troubled them. Several vocalized the social ramifications of giving in to engineers' resistance:

I think the risk of not talking about leadership ... might have . . consequences. I would really want to see more engineers running our city or running our financial institutions or parts of our government, just because of the technical ability and all of the other problem-solving, critical thinking skills.

For the engineering entrepreneurs, separating technical problem solving, process optimization, and innovation from leadership and management was equivalent to leaving projects half finished. They did not expect all engineers to follow in their footsteps and start their own businesses, but they did believe that engineers at all levels of an organization could influence change from within:

Intrapreneurship is something that has to be kind of pushed. I love that word. It [describes] the ... people who ultimately want to lead change from within as opposed to external. ... You don't have to start your own company to be an entrepreneur, you can be an entrepreneur from within as well.

Related to the entrepreneurs' persistent advocacy for internally and externally driven change was their reliance on experimentation and risk taking to drive innovation. In fact, one of the most prominent themes from this focus group was the importance of learning from mistakes by taking calculated risks in the service of one's vision. 
Inter-subjective analysis of Engineering Leadership/ C. Rottmann, D. W. Reeve, R. Sacks, \& M. Klassen 158

One of the things that results in great leaders is the ability to take risks.... That is what I think embodies a great leader-[having] more confidence that a decision is going to work out more optimally than it ultimately could.

Engineering entrepreneurs' optimism, open-ended experimentation, and focus on inspiring change in themselves and others without fixing success to a specific outcome led them to view their professional colleagues, not simply as technical problem solvers, but also as industry leaders and societal change agents.

\section{Politicians: Engineers Can Use Their Problem-Solving Skills to Serve Society}

The two politicians (Members of Parliament) with engineering training who agreed to participate in an interview spent time in two different organizational contexts: as local representatives of their respective ridings and as federal representatives of a political party. Compared with most of their professional engineering colleagues, the politicians were more likely to get their ideas broadly implemented because they had access to national decision-making networks with legislative impact. Therefore, we were not surprised to find that they embraced a leadership identity:

Yes, I am a leader. I get involved. When I throw myself into situations, whether at work or outside of work, I step up when I notice nobody else is leading-not in an overly assertive way, but every team requires a certain level of leadership and direction. So, when the need arises, I will step up.

For both Members of Parliament, leadership involved taking responsibility to support or direct projects with social impact. Neither of them had set out to become politicians, but after involving themselves in community-based causes, both were encouraged to run for office. A salient feature of their professional identities was their public service orientation:

I was speaking to students about politics on the Hill [Parliament] the other day and they asked me about governing the nation. I didn't think my motivation was to govern the nation. I thought it was to see how many people I could help by using the government.

Rather than setting out to lead or regulate others, both politicians had run for office to get something practical accomplished on a larger scale than would have been possible if they had acted only as individuals. While politicians with a range of educational backgrounds likely share this desire to scale up their impact, the ones we interviewed believed their engineering training and work experience uniquely positioned them to contribute to industry-relevant policies and legislative decisions in technology, infrastructure, transportation, and defence.

I was on the transport committee and one of the MPs said, "We should get GPS [Global Positioning Systems] installed in all of the airports in Canada." What she didn't understand is that you don't put a GPS in the ground. You put it in the vehicle that is travelling to where you want to go. So I explained it to her and she said, "Oh, you engineers!" Engineers have often managed large-scale projects in transportation and defence, so we can use that industry knowledge to make policies that make sense. Nobody else has that kind of experience here. 
Inter-subjective analysis of Engineering Leadership/ C. Rottmann, D. W. Reeve, R. Sacks, \& M. Klassen 159

In addition to their industry-based knowledge and experience, the engineer-politicians we interviewed were advantaged by their problem-solving orientations:

The scientific method is the foundation of engineering thinking. It's not really technical. ... Technical work involves knowing the solution to a certain problem, but there is always that truly original problem that doesn't have a solution. How do you even conceive of the method for arriving at that solution? The scientific method takes a certain fearlessness. You don't look at a problem and say, "This is something that can't be solved," and run away from it. Instead, it's like, "I see a problem. How can I solve this problem?"

Supplementing their fearless, disciplined problem-solving tendencies, both politicians found their even-tempered approach to resolving hotly contested political issues balanced the "firebrand" approach of their colleagues:

I guess I am a pretty rational person. I don't like firebrand speakers, demagogues, people who give purely emotional speeches. ... When I give an argument, maybe it is not with enough passion, but it has to have that founding in facts and information. Otherwise you lead people down the wrong path. I think most engineers tend to think this way. ... Recently, I was part of a taskforce to look at pensions and benefits. It was very quantitative, but there is also an emotional side to it in terms of what is fair. My engineering background allowed me to be successful as part of the team that came up with what I think just about everybody in the country agrees is a pretty good solution.

While very few Canadian politicians have engineering backgrounds, these quotations illustrate the important and unique leadership contributions made by professional engineers engaged in federal politics. The engineer-politicians we interviewed easily transferred their training, problem-solving skills, and industry experience to public service in ways that allowed their colleagues to implement practical, data-informed, emotionally balanced solutions.

\section{Student Interns: Impactful Leaders Help New Engineers Bridge the Theory- Practice Gap}

The undergraduate student interns in our final two focus groups were in the midst of an institutional transition. They were six months into a 16-month internship between their third and fourth years of engineering. They appreciated the rigorous technical preparation they had received in their first three years of university but believed their professors had left a leadership vacuum when it came to filling the "theory-practice gap" in their education:

I think what this university doesn't focus on a lot, and everybody knows it, is practical skills: actually applying our technical knowledge. How many times have I gone from first principles-which I know a lot about-to actually applying it to physically build something? I have done it once. I think it is something you need as an engineer.

Compounding interns' concerns about this theory-practice gap was their experience being introduced, for the first time in many cases, to software and other time-saving tools favoured by their employers: 
I feel that what we learn in Civil is really good, but not up to date. When I got to work, I did a structural analysis and designed a beam slab. It took me 16 pages and two days of hand calculations. I gave it to my manager and he said, "Wow, you are a really smart person, this is fantastic, but I can't believe you did that. Check out this software." In two minutes, he got the same answer. It was heartbreaking.

This intern was so focused on her failure to be efficient and the university's failure to expose her to all relevant software packages that she underappreciated her success-her ability to accurately apply foundational knowledge and technical skills to a practical problem with the precision of a machine. As it turned out, she did not have a theory-practice skills gap. She was just less efficient at slab design than her senior colleagues who had been doing this work for decades and had a relevant software package at their disposal. The time-saving strategy she described happened to be technical in nature, but many other interns described efficiencies gained through social, interpersonal, and organizational learning:

It is really important to be able to network your way through to get things done. Knowing who to talk to is really important. A lot of times, I wasted time trying to find the right people and I got bounced around.... So it's really important to learn who to talk to and know who to direct your questions to right away to get stuff done.

The steep learning curve experienced by student interns in all domains helped them recognize the practical value of interpersonal, organizational, and communication skills:

I don't think I cared about soft skills in first year because I don't think I knew how much it would matter.... We are just thinking, "Math is really hard and it is really important, so we better work really hard on it." But then we underestimate the fact that talking to people is really hard too.

The interns were so focused on their transitions from school to work, from theory to practice, and from technical to interpersonal domains that they rarely positioned themselves as leaders. They did, however, appreciate the leadership efforts of workplace mentors. When we asked them to identify a leader they admired, many of them named the engineers to whom they reported-team leaders, technical specialists, and managers. We found it interesting that they selected leaders primarily in middle rather than senior management positions. These middle managers actively encouraged them to experiment with problem-solving strategies most commonly used in their respective industries, thereby catalyzing deeply contextualized, experiential learning (Kolb, 1984) opportunities for their new engineering colleagues. The interns' shared conception of leadership as instruction, facilitation, and mentorship was not surprising given their organizational locations as boundary spanners between the worlds of school and work.

Please see Table 2 for a summary of our findings connecting participants' organizational locations and leadership insights. 
Table 2.

Engineering Leadership Insights by Organizational Location

\begin{tabular}{|c|c|c|c|c|}
\hline Role & Where they work & $\begin{array}{l}\text { Individuals \& } \\
\text { processes to } \\
\text { which they have } \\
\text { access }\end{array}$ & $\begin{array}{l}\text { Definition of en- } \\
\text { gineering leader- } \\
\text { ship }\end{array}$ & $\begin{array}{l}\text { Insights about engi- } \\
\text { neering leadership }\end{array}$ \\
\hline $\begin{array}{l}\text { Engineers in } \\
\text { industry }\end{array}$ & $\begin{array}{l}\text { Project design } \\
\text { teams located in } \\
\text { different depart- } \\
\text { ments }\end{array}$ & $\begin{array}{l}\text { Technical spe- } \\
\text { cialists, team } \\
\text { leaders, team } \\
\text { members and } \\
\text { suppliers } \\
\text { Design processes }\end{array}$ & $\begin{array}{l}\text { Raising the bar } \\
\text { through profes- } \\
\text { sional compe- } \\
\text { tence, otherwise } \\
\text { known as "lead- } \\
\text { ing by example" }\end{array}$ & $\begin{array}{l}\text { Identification as a } \\
\text { leader in the field } \\
\text { depends on one's } \\
\text { demonstration of key } \\
\text { engineering compe- } \\
\text { tencies. }\end{array}$ \\
\hline $\begin{array}{l}\text { Human } \\
\text { resource pro- } \\
\text { fessionals \& } \\
\text { educators }\end{array}$ & $\begin{array}{l}\text { Central manage- } \\
\text { ment offices }\end{array}$ & $\begin{array}{l}\text { Senior leaders } \\
\text { and recent hires } \\
\text { Onboarding pro- } \\
\text { cesses }\end{array}$ & $\begin{array}{l}\text { Aligning one's } \\
\text { contributions } \\
\text { with organiza- } \\
\text { tional needs }\end{array}$ & $\begin{array}{l}\text { Engineers who merge } \\
\text { their technical, inter- } \\
\text { personal, and com- } \\
\text { munication skills to } \\
\text { support organization- } \\
\text { al needs are always in } \\
\text { demand. }\end{array}$ \\
\hline $\begin{array}{l}\text { Engineer-en- } \\
\text { trepreneurs }\end{array}$ & $\begin{array}{l}\text { Start-ups (inde- } \\
\text { pendent and ac- } \\
\text { quired by larger } \\
\text { organizations) }\end{array}$ & $\begin{array}{l}\text { Small creative } \\
\text { teams or part- } \\
\text { nerships } \\
\text { Product market- } \\
\text { ing processes }\end{array}$ & $\begin{array}{l}\text { Driving innova- } \\
\text { tive, marketable } \\
\text { change }\end{array}$ & $\begin{array}{l}\text { Engineers can use } \\
\text { their innovative } \\
\text { ideas to bring about } \\
\text { technical, organiza- } \\
\text { tional, and economic } \\
\text { change. }\end{array}$ \\
\hline $\begin{array}{l}\text { Engineer- } \\
\text { politicians }\end{array}$ & $\begin{array}{l}\text { Local and federal } \\
\text { political offices }\end{array}$ & $\begin{array}{l}\text { Local residents } \\
\text { and party mem- } \\
\text { bers } \\
\text { National deci- } \\
\text { sion-making } \\
\text { network with } \\
\text { legislative impact }\end{array}$ & $\begin{array}{l}\text { Leveraging } \\
\text { problem-solving } \\
\text { skills to serve } \\
\text { society }\end{array}$ & $\begin{array}{l}\text { Engineers can use } \\
\text { design principles, } \\
\text { industry experience, } \\
\text { and data-informed, } \\
\text { rational decision } \\
\text { making to serve and } \\
\text { influence society. }\end{array}$ \\
\hline Interns & $\begin{array}{l}\text { University and } \\
\text { industry (project } \\
\text { teams) }\end{array}$ & $\begin{array}{l}\text { Instructors, } \\
\text { design teams, } \\
\text { peers, team lead- } \\
\text { ers, mentors } \\
\text { Learning \& de- } \\
\text { sign processes }\end{array}$ & $\begin{array}{l}\text { Mentoring, } \\
\text { coaching, and } \\
\text { empowering col- } \\
\text { leagues to bridge } \\
\text { the theory-prac- } \\
\text { tice gap. }\end{array}$ & $\begin{array}{l}\text { Engineers who cata- } \\
\text { lyze the professional } \\
\text { learning of junior col- } \\
\text { leagues make influen- } \\
\text { tial leaders. }\end{array}$ \\
\hline
\end{tabular}


Inter-subjective analysis of Engineering Leadership/ C. Rottmann, D. W. Reeve, R. Sacks, \& M. Klassen 162

\section{Discussion: Co-constructing the Elephant}

The five narrative layers above invite us into the worlds of engineers in industry, human resource professionals, entrepreneurs, politicians, and undergraduate engineering students. By reading them in succession we can see that engineers in different roles responded to the word "leadership" in distinct, experientially conditioned ways. Engineers in industry spoke about professional competence, human resource professionals discussed organizational fit, entrepreneurs told us about innovative change, politicians raised the issue of public service, and student interns identified mentors who helped them bridge the theory-practice gap. In each case, the word "leadership" was intersubjectively available (Schutz, 1967) to participants, yet it conjured up different images in their minds based largely on their immediate organizationally mediated experiences. To return to the blind men and elephant analogy, we are left with five seemingly irreconcilable leadership metaphors-a collection of tails, stomachs, ears, tusks, and trunks with no elephant. In this section, we connect the insights of each group to their respective organizational locations and discuss how our findings contribute to the literature on engineering leadership. We conclude by constructing a poly-vocal definition of engineering leadership.

Our findings suggest that the domains over which engineers have control shape their leadership insights. As with the blind men whose varied conceptions of "elephant" depended on their differential tactile access, the leadership definitions of five engineering subgroups depended on their differential access to organizational influence. For example, engineers working in technical industries shared control over the project design process and defined leadership as modelling professional competence. Human resource professionals whose primary influence occurred in their socialization of newly hired engineers defined engineering leadership as aligning employees' contributions with organizational needs. Entrepreneurs whose influence peaked when their innovative ideas gained market attention defined engineering leadership as driving innovative, marketable change. Politicians whose election to office depended on their public service records in the eyes of the electorate defined engineering leadership as problem solving in service of society. Finally, student interns whose workplace integration depended on their practical application of engineering principles defined engineering leadership as helping colleagues bridge the theory-practice gap.

If leadership is primarily about influence, it makes sense that differently positioned engineers would ground their respective definitions of leadership in the domains over which they have some degree of authority. The psychological construct "locus of control" is instructive here (Rotter, 1966). Just over five decades ago, Julian Rotter found that some participants in his experimental studies on reinforcement attributed random outcomes to internal factors, such as their own behaviour or competence, while others attributed the exact same outcomes to external factors, such as the environment or the behaviour of powerful others. As professional problem solvers, engineers are trained to devise systems, components and processes to meet desired goals (Accreditation Board for Engineering and Technology, 2011). In other words, they are trained to be agents in outcome-driven design. While some engineering students may enter their academic programs with an external locus of control, their training is likely to either socialize them out of this habit or deter them from the profession. Between the prominence of solvable problems in the field of engineering and the tight coupling of leadership with human agency, it is not surprising that par- 
ticipants' leadership definitions related directly to the domains over which they had some level of influence. Rotter's concept-locus of control-helps us explain not only why differently located engineers define leadership differently but also why many engineers who lack control over certain aspects of organizational life may resist identifying engineering as a leadership profession. If professional engineers overwhelmingly adopt an internal locus of control, they may be more likely to classify any domain over which they lack control as a "non-engineering" domain. Perhaps if we as a society accepted engineers' influence over a wider range of issues, or if engineers as a profession collectively participated in making decisions that extended beyond the realm of technical problem solving, we would see an improvement in their acceptance of engineering as a leadership profession.

Shifting from psychological theory to the literature on engineering leadership, our findings make the greatest contribution to the fifth stream we reviewed: conceptual explorations of engineering leadership. They organizationally contextualize Mallette's (2005) Theory Pi, extend Rottmann et al.'s (2015) three orientations to engineering leadership, add a fourth and fifth vector to Robledo et al.'s (2012) three-vector model of creative leadership, and flesh out Ahn et al.'s (2014) five qualitative engineering leadership themes. Mallette's (2005) Theory Pi tightly corresponds with the definition of leadership generated by our first occupational subgroup-engineers in technical industries-but it contradicts the leadership narratives of human resource professionals, politicians, and entrepreneurs. Our findings demonstrate that while Theory Pi is too narrow for engineers in non-traditional roles, it is likely to achieve a high degree of resonance with engineers in technical design roles. Similarly, our current analysis suggests that while Rottmann et al.'s grounded theory of engineering leadership (2015) holds meaning for technical specialists, team leaders, and senior administrators of engineering-intensive firms, it says little about the influence of engineers who work in non-traditional roles, such as politicians. Our findings extend the earlier work of Rottmann et al. (2015) by contributing a fourth public service leadership orientation to their grounded theory of engineering leadership. Not unlike the two conceptual studies cited above, Robledo and his colleagues' (2012) three-vector model of creative leadership accounts for only three domains of engineering influence: the group, the work, and the organization. Our analysis of interviews and focus groups with engineering entrepreneurs and politicians provides conceptual details in support of one additional vector: societal. Finally, Ahn and his colleagues (2014) account for the economic and political dimensions of engineering leadership, but they fail to bring their named dimensions to life using quotations from the 23 engineers they interviewed. Our five narrative layers neatly map onto and flesh out their five themes. In particular, project-based engineers' narratives flesh out Ahn et al.'s competency theme, while the narratives of human resource professionals add details to their organization and people themes. Entrepreneurs' and politicians' leadership narratives respectively contextualize Ahn et al.'s economic and society themes, while those of interns characterize their people and competency themes.

Overall, our study extends the existing body of engineering leadership literature by accounting for the experiences of a more organizationally diversified sample of engineers. In particular, our findings help us empirically synthesize a more comprehensive picture of engineering leadership by weaving together the insights of engineers in industry, human resource professionals, entrepreneurs, politicians, and student interns. So what does our elephant-engineering leadership-look like? If we integrate our five narrative layers, 
Inter-subjective analysis of Engineering Leadership/ C. Rottmann, D. W. Reeve, R. Sacks, \& M. Klassen 164

engineering leadership involves varied combinations of the following elements: mastery of key engineering competencies, organizational awareness, motivation to drive innovative change, a public service orientation, and the ability to catalyze the learning of others.

\section{Conclusions}

We began this paper with two research questions: How do engineers in different roles define leadership, and how do their organizational locations shape their insights? Weaving together the perspectives of engineers in industry, human resource professionals, entrepreneurs, politicians, and interns, we learned that engineering leadership involves at least five elements. These include a mastery of key engineering competencies, organizational awareness, motivation to drive innovative change, a public service orientation, and the ability to catalyze the learning of others. In response to our second research question, we learned that engineers' relative levels of influence over workplace structures, tasks, information, and people shaped their particular insights about leadership. Engineers with influence over technical problem-solving processes experienced leadership as a set of professional competencies; human resource professionals with influence over employee induction processes defined leadership as the alignment of employees' skills with organizational needs; entrepreneurs with influence over innovation characterized leadership as the implementation of marketable change; politicians with influence over legislation and policy decisions defined leadership as public service; and interns whose emerging influence was catalyzed by workplace mentors defined leadership as the instructional capacities of experienced colleagues. On its own, each insight tells us little about our phenomenon of interest; but together the five perspectives allow us to intersubjectively define, study, realize, and teach engineering students about leadership in ways that decrease the likelihood of resistance. To the extent that we privilege one set of perspectives over another, we narrow the breadth and potential utility of the engineering leadership reform movement. Instead, by connecting five diverse perspectives and taking the resulting educational implications into account, we can use our personal points of impact to collectively catalyze dynamic, innovative, and widely meaningful change.

\section{Implications for Engineering Leadership Educators}

Our findings suggest that engineers in different roles experience and define leadership in distinct, organizationally contextualized ways. Given this finding, it is important for us as engineering leadership educators to expose our students to the full range of career options and organizational contexts open to engineering graduates. We can do this in a variety of ways. We can help them expand their professional aspirations by inviting engineering alumni with non-traditional career trajectories into the classroom. We can present students with the five leadership narratives of engineers in technical, human resource, entrepreneurial, political, and team leadership positions, then ask them to reflect on their relative affinity for each role. We can conduct a survey of engineering alumni to see where they are now, then present the results to our students; and we can ask our students to fill out validated inventories like the Myers-Briggs Type Indicator and the Strong Interest Inventory, then provide them with National Occupational Classification (NOC) descriptions of jobs most often aligned with their results. 
Second, the organizationally contextualized nature of engineers' leadership narratives in our study demands not only that we share alternative career options with our students but also that we convey to them the importance of developing organizational awareness. We can accomplish this goal by taking them on field trips to engineering workplaces that range in size, discipline, and organizational structure. Within the classroom, we can also assign them group projects involving industry-based interviews; present them with authentic case studies based on the experiences of engineers in public, private, and nonprofit sectors; punctuate their internship experiences with iterative reflection on organizational issues; and invite them to reflect on the organizational structures of institutions with which they are most familiar (e.g., university, religious institutions, community centres, family, and summer/part-time workplaces).

Third, our findings suggest that the domains over which engineers have some degree of influence shape their definitions of leadership. Therefore, it behooves us to examine the relationship between their specific conceptions of leadership and their relative levels of authority at work. While our study does not support the deterministic argument that leadership is limited to individuals at the top of the organizational hierarchy, it does suggest that engineers' roles, responsibilities, networks, and varied access to workplace processes influence their varied understandings of leadership within the profession. Engineers in five different roles were able to exercise influence over tasks, processes, and, in some cases, colleagues, but the nature of that influence varied in relation to the information, individuals, and structures to which each occupational subgroup had access. As engineering educators, we need to help our students appreciate both formal and informal modes of leadership practised by engineers in a range of organizational roles and locations. To the extent that our students expand their definitions of leadership to include collaborative, informal modes of influence, we will be helping them embrace the idea of engineering as a leadership profession. Related to this point, if a critical mass of engineers accept these broader, professionally relevant forms of leadership, they may be more inclined to extend their spheres of influence and increase their collective impact on society. Finally, if we wish to increase engineers' professional identification as leaders, we as a society should begin by extending their current spheres of influence.

\section{Implications for Leadership Educators in Other Professions}

Our engineering leadership project was initially driven by our observation of and dissatisfaction with the poor fit between traditional leadership theories and engineering students' professional identities. While it would be an error to generalize our specific findings to other higher education faculties, it would be worth asking students in other professional programs how well their developing professional identities fit with their conceptions of leadership. To what extent do undergraduate students studying medicine, law, nursing, architecture, education, or social work characterize their work as leadership? How can we as leadership educators help them experience their work as leadership, and leadership as their work?

Professional identities aside, explicit leadership training outside of MBA programs is a relatively recent, large-scale educational reform idea proposed by national academies, provincial regulatory bodies, professional advocacy groups, and accreditation bodies hoping to influence the social, political, and economic impact of specialists whose primary 
training is in a non-traditional leadership field. Our key recommendation for leadership educators and researchers in professional faculties is to ground their empirical inquiries and instructional practices in the experiences of alumni in their respective fields. This kind of discipline-specific research can form a useful foundation for experientially informed training that will benefit leadership educators by decreasing their students' resistance to the idea of engineering leadership, physician leadership, teacher leadership, and other forms of professional influence.

Amanda Goodall has theorized this kind of professional influence through her Expert Leadership Theory, which she based on earlier findings that organizations led by individuals with a deep understanding of the core business of their firms performed better than did those led by generalists (Goodall, 2009, 2011, 2012, 2013). Expert leaders, according to Goodall, develop their skills through technical or clinical training, relevant professional or industry experience, and leadership education. Building on Goodall's theory, we believe that faculty members and instructors in a range of higher education fields can prepare their students for leadership responsibilities by supplementing technical, theoretical, and clinical training with professionally relevant leadership education based on the workplace realities of their alumni. This kind of "heterogeneous" (Law, 1987) professional education will benefit leadership educators, students, professional associations, and the public.

Leadership educators and students will benefit from experientially based, contextually relevant curricula, while professional societies will benefit from the expanding influence of members who not only learn how to lead in their chosen disciplines but also accept leadership responsibilities in their respective workplaces. Most important, in the long term, professionally meaningful leadership education may indirectly benefit society. Once doctors, lawyers, engineers, architects, teachers, nurses, social workers, and other professionals gain access to domain-specific leadership opportunities in their organizations and jurisdictionally relevant policy-making channels (municipal, provincial, federal), they can support experientially based improvements in health care, municipal infrastructure, technology, justice, education, and social services.

\section{Limitations and Next Steps}

Our methodological decisions have allowed us to examine engineering leadership from the perspective of five differently located groups of engineers, but they have also limited the scope of our findings. By organizing people into occupational subgroups, we have masked individual diversity within each group. We plan to address this challenge through in-depth, career history interviews with engineering leaders across the career trajectory. At the other end of the methodological spectrum, our analytical decisions have prevented us from assessing the correlation between engineers' organizational authority and their perceptions of leadership. A large-scale survey of engineers who work in different industries, sectors, and organizational locations would allow us to extend and possibly generalize our findings to a wider population: licensed engineers in Canada. Finally, at a more applied level, we, as engineering leadership educators, can implement the ideas we have recommended to others and evaluate their impact on our own students. As the higher education reform movements initiated by Engineers Canada and the National Academy of Engineering expand and take shape across local, provincial, national, and global jurisdictions, we can use the five competency-based elements of our emergent en- 
Inter-subjective analysis of Engineering Leadership/ C. Rottmann, D. W. Reeve, R. Sacks, \& M. Klassen 167

gineering leadership definition to formally evaluate a range of programmatic initiatives across Canadian faculties of engineering. While these iterative evaluations of engineering leadership education may not be transferable to other disciplines, they do provide a comparative program evaluation model for leadership education in other professions.

\section{Acknowledgements}

This study was conducted with support from our four partner companies, ERCO Worldwide, Hatch, Google Canada, and Vale, as well as from the Dean's Strategic FundFaculty of Applied Science and Engineering at the University of Toronto. We are grateful to these organizations and to the 82 engineers who agreed to share their insights with us. Thank you as well to Jordan Daniow, Rostom Mesil, and Serhiy Kovalchuk for translating our abstract into French and/or arranging for the translation.

\section{References}

Accreditation Board for Engineering and Technology. (2011). Criteria for accrediting engineering programs: Effective for reviews during the 2012-2013 accreditation cycle.

Ahn, B., Cox, M. F., London, J., Cekic, O., \& Zhu, J. (2014). Creating an instrument to measure leadership, change, and synthesis in engineering undergraduates. Journal of Engineering Education, 103(1), 115-136. doi:10.1002/jee.20036

Athreya, K., S., Bhandari, N., Kalkhoff, M. T., Rover, D. T., Black, A. M., Miskioglu, E. E., \& Mickelson, S. K. (2010, October). Work in progress-Engineering Leadership Program: A thematic learning community. Paper presented at the ASEE/IEEE Frontiers in Education Conference, Washington, DC.

Baranowski, M. (2011). Rebranding engineering: Challenges and opportunities. The Bridge, 41(2), 12-16.

Bayless, D. J. (2013, June). Developing leadership skills in engineering students: Foundational approach through enhancement of self-awareness and interpersonal communication. Paper presented at the Canadian Engineering Education Association Conference, Montreal, QC.

Bergeron, H. E. (2001). A perspective on the need to give an introduction to engineering management to all engineering students. Leadership and Management in Engineering, 1(1), 26-29. doi:10.1061/(ASCE)1532-6748(2001)1:1(26)

Bishop, W. D. (2013, June). The assessment of leadership outcomes in capstone projects using anonymous peer feedback. Paper presented at the Canadian Engineering Education Association Conference, Montreal, QC.

Bonasso, S. G. (2001). Engineering, leadership, and integral philosophy. Journal of Professional Issues in Engineering Education and Practice, 127(1), 17-25.

Cain, K., \& Cocco, S. (2013, June). Leadership development through project based learning. Paper presented at the Canadian Engineering Education Association, Montreal, QC.

Cassin, R. B. (2003). Leadership and communication in civil engineering: Past, present, and future. Leadership and Management in Engineering, 3(3), 145-147. doi:10.1061/ (ASCE)1532-6748(2003)3:3(145) 
Colcleugh, D., \& Reeve, D. W. (2013, June). Translating a corporate leadership philosophy and practice to the engineering classroom. Paper presented at the Canadian Engineering Education Association Conference, Montreal, QC.

Denzin, N. K. (2002). The interpretive process. In A. M. Huberman \& M. B. Miles (Eds.), The Qualitative Researcher's Companion (pp. 349-366). Thousand Oaks, CA: Sage.

Denzin, N. K., \& Lincoln, Y. S. (2003). Strategies of qualitative inquiry (2nd ed.). Thousand Oaks, CA: Sage.

Doboli, S., Tang, W., Ramnath, R., Impagliazzo, J., VanEpps, T., Agarwal, A., .. . Currie, E. H. (2010, October). Models of entrepreneurship education and its roles in increasing creativity, innovation and leadership in computer science and engineering students. Paper presented at the ASEE/IEEE Frontiers in Education Conference, Washington, DC.

Ellis, L. A., \& Petersen, A. K. (2011). A way forward: Assessing the demonstrated leadership of graduate civil engineering and construction management students. Leadership and Management in Engineering, 11(2), 88-96.

Emison, G.A. (2011). Transformativeleadership for engineering in a time of complexity. Leadership and Management in Engineering, 11(2), 97-102.

Engineers Canada. (2009). Leading a Canadian future: The new engineer in society. Ottawa, ON: Canadian Engineering Leadership Forum, Engineers Canada.

Evans, G. J., Reeve, D. W., Sheridan, P. K., McGuire, M., Minnella, K., Oliva-Fisher, E., ... McAlary, T. (2013, June). Incorporating team-effectiveness as a learning objective in the design project within a technical core course. Paper presented at the Canadian Engineering Education Association Conference, Montreal, QC.

Falkenburg, D. R. (2005). Information technology in support of engineering education: Lessons from the Greenfield Coalition. In National Academy of Engineering (Ed.), Educating the engineer of 2020: Adapting engineering education to the new century (pp. 69-81). Washington, DC: National Academies Press.

Farr, J. V., \& Brazil, D. M. (2009). Leadership skills development for engineers. Engineering Management Journal, 21(1), 3-8.

Farr, J. V., Walesh, S. G., \& Forsythe, G. B. (1997). Leadership development for engineering managers. Journal of Management in Engineering, 13(4), 38-41.

Flowers, R. B. (2002). Leadership as a responsibility. Leadership and Management in Engineering, 2(3), 15-19. doi:10.1061/(ASCE)1532-6748(2002)2:3(15)

Foster, J. A., \& Sheridan, P. K. (2013, June). Exploring design identity through a "reverse engineer and improve" values elicitation activity. Paper presented at the Canadian Engineering Education Association Conference, Montreal, QC.

Froyd, J. E. (2005). The Engineering Education Coalitions program. In National Academy of Engineering (Ed.), Educating the engineer of 2020: Adapting engineering education to the new century (pp. 82-97). Washington, DC: National Academies Press. 
Gheorghe, F., Hodgson, A. J., \& Van der Loos, M. (2013, June). Improving outcomes in student design courses through qualitative user research and contextual immersion. Paper presented at the Canadian Engineering Education Association Conference, Montreal, QC.

Glaser, B. (1965). The constant comparative method of qualitative analysis. Social Problems, 12(4), 436-445.

Glaser, B., \& Strauss, A. (1967). The discovery of grounded theory. Chicago, IL: Aldine.

Goodale, M. J. (2005). The right stuff: Traits and skills of effective leaders. Leadership and Management in Engineering, 5(1), 7-8. doi:10.1061/(ASCE)1532-6748(2005)5:1(3)

Goodall, A.H.(2009). Highly cited leaders and the performance of research universities. Research Policy, 38(7), 1079-1092. doi:10.1016/j.respol.2009.04.002

Goodall,A.H.(2011).Physician-leadersandhospitalperformance:Isthereanassociation? Social Science \& Medicine, 73(4), 535-539. doi:10.1016/j.socscimed.2011.06.025

Goodall, A. H. (2012). A theory of expert leadership. Bonn, Germany: IZA.

Goodall, A. H. (2013). Why we need expert leaders. Retrieved from http://www. amandagoodall.com/WhyweneedExpertLeaders-DevelpingLeadersDec2012.pdf

Graham, R. (2012). Achieving excellence in engineering education: The ingredients of successful change. London, UK: The Royal Academy of Engineering \& Massachusetts Institute of Technology.

Graham, R., Crawley, E., \& Mendelsohn, B. R. (2009). Engineering leadership education: A snapshot review of international good practice. Cambridge, MA: Bernard M. Gordon MIT Engineering Leadership Program.

Grasso, D., \& Martinelli, D. (2007). Holistic engineering. The Chronicle of Higher Education, 53(28), B8-B9.

Hensey, M. (2001). Innovations and best practices: Leadership development and retention. Leadership and Management in Engineering, 1(1), 37-41. doi:10.1061/ (ASCE)1532-6748(2001)1:1(37)

Hsiao, A. (2013, June). Developing an entrepreneurial mindset in engineering students. Paper presented at the Canadian Engineering Education Association Conference, Montreal, QC.

Ivey,J.M.(2002). Five critical components ofleadership. Leadership and Management in Engineering, 2(2), 26-28. doi:10.1061/(ASCE)1532-6748(2002)2:2(26)

Kalonji, G. (2005). Capturing the imagination: High priority reforms for engineering educators. In National Academy of Engineering (Ed.), Educating the engineer of 2020: Adapting engineering education to the new century (pp. 146-150). Washington, DC: National Academies Press.

Katehi, L. (2005). The global engineer. In National Academy of Engineering (Ed.), Educating the engineer of 2020: Adapting engineering education to the new century (pp. 151-155). Washington, DC: National Academies Press. 
Inter-subjective analysis of Engineering Leadership/ C. Rottmann, D. W. Reeve, R. Sacks, \& M. Klassen 170

Kenner, T., \& Isaak, M. A. (2004). Effective leadership development in a civilengineering culture: Finding the balance-point between experience and experiment. Leadership and Management in Engineering, 4(3), 105-109. doi:10.1061/(ASCE)15326748(2004)4:3(105)

Kerns, S. E., Miller, R. K., \& Kerns, D. V. (2005). Designing from a blank slate: The development of the initial Olin College curriculum. In National Academy of Engineering (Ed.), Educating the engineer of 2020: Adapting engineering education to the new century (pp. 98-113). Washington, DC: National Academies Press.

Kirschenman, M. (2011). Leadership of multidisciplinary programs and systems. Leadership and Management in Engineering, 11(2), 137-140.

Kolb, D. A. (1984). Experiential learning: Experiences as the source of learning and development. Englewood Cliffs, NJ: Prentice-Hall.

Law, J. (1987). Technology and heterogeneous engineering: The case of the Portuguese expansion. In W. E. Bijker, T. P. Hughes \& T. Pinch (Eds.), The social construction of technological systems (pp. 111-134). Cambridge, MA: MIT Press.

Loui, M. C. (2005). Ethics and the development of professional identities of engineering students. Journal of Engineering Education, 94(4), 383-390.

Mallette, L. (2005, March). Theory Pi: Engineering leadership not your theory $x, y$, or $z$ leaders. Paper presented at the Institute of Electrical \& Electronic Engineers Aerospace Conference, Big Sky, MT.

Martines-Corcoles, M., Gracia, F. J., Tomas, I., Peiro, J. M., \& Schobel, M. (2013). Empowering team leadership and safety performance in nuclear power plants: A multilevel approach. Safety Science, 51(1), 293-301. doi:10.1016/j.ssci.2012.08.001

Mawson, T. C. (2001). Ready! Aim! Inspire! Leadership in engineering. Leadership and Management in Engineering, 1(2), 50-51. doi:10.1061/(ASCE)1532-6748(2001)1:2(50)

McCuen, R. H. (1999). A course on engineering leadership. Journal of Professional Issues in Engineering Education and Practice, 125(3), 79-82.

McMartin, D. W. (2013, June). Service learning and team work: Elements of leadership. Paper presented at the Canadian Engineering Education Association Conference, Montreal, QC.

Miles, M. B., \& Huberman, A. M. (1994). Qualitative data analysis: An expanded sourcebook (2nd ed.). Thousand Oaks, CA: Sage.

Mumford, M. D., Scott, G. M., Gaddis, B., \& Strange, J. M. (2002). Leading creative people: Orchestrating expertise and relationships. The Leadership Quarterly, 13(6), 705-750. doi:10.1016/S1048-9843(02)00158-3

National Academy of Engineering. (2004). The engineer of 202O: Visions of engineering in the new century. Washington, DC: National Academies Press.

National Academy of Engineering. (2005). Educating the engineer of 2020: Adapting engineering education to the new century. Washington, DC: National Academies Press.

National Academy of Engineering. (2012). Infusing real world experiences into engineering education. Washington, DC: National Academy of Engineering. 
Ning, H., Zhou, M., Lu, Q., \& Wen, L. (2012, October). Team traditionality in the relationship between authority leadership and team organizational citizenship behavior. Paper presented at the International Conference on System Science, Engineering Design and Manufacturing Informatization, Chengdu, China.

Osagiede, A., Farmer Cox, M., \&Ahn, B. (2013, June). Purdue University's Engineering Leadership Program: Addressing the shortfall of engineering leadership education. Paper presented at the 120th ASEE Annual Conference and Exposition, Atlanta, GA.

Passow, H. J. (2012). Which ABET competencies do engineering graduates find most important in their work? Journal of Engineering Education, 101(1), 95-118.

Pierson, G. J. (2013). Leadership in the world's third oldest profession: Keynote speech to the American Society of Civil Engineers leadership breakfast. Leadership and Management in Engineering, 13(2), 83-85. doi:10.1061/(ASCE)LM.1943-5630.0000224

Pitts, S., Klosterman, S., \& McGonagle, S. (2013, June). A successful approach to educating engineering leaders at the graduate level. Paper presented at the Canadian Engineering Education Association Conference, Montreal, QC.

Reeve, D. W. (2010). There is an urgent need for engineering leadership education. Engineering Leadership Review, 1(1), 1-6.

Reeve, D. W., Rottmann, C., \& Sacks, R. (2015, June). The ebb and flow of engineering leadership orientations. Paper presented at the American Society of Engineering Education Annual Conference and Exposition, Seattle, WA.

Reeve, D. W., Sacks, R., \& Rottmann, C. (2014, June). A responsibility to promote leadership: Engineering entrepreneurs speak back to resistance. Paper presented at the Canadian Engineering Education Association Conference, Calgary, AB.

Reeve, D. W., Sacks, R., Rottmann, C., Daniels, F., \& Wray, A. (2013, June). Engineer leadership in organizations and the implications for curriculum development. Paper presented at the Canadian Engineering Education Association Conference, Montreal, QC.

Reeve, D. W., Simpson, A. E., \& Evans, G. J. (2010, June). The leader-engineer: Capabilities, competencies and attributes. Paper presented at the Canadian Engineering Education Association Conference, Kingston, ON.

Riley, D. R., Horman, M. J., \& Messner, J. I. (2008). Embeddingleadership development in construction engineering and management education. Journal of Professional Issues in Engineering Education and Practice, 134(2), 143-151.

Robledo, I. C., Peterson, D. R., \& Mumford, M. D. (2012). Leadership of scientists and engineers: A three-vector model. Journal of Organizational Behavior, 33(1), 140-147. doi:10.1002/job.739

Roncin, A. (2013, June). Thoughts on engineering ethics education in Canada. Paper presented at the Canadian Engineering Education Association Conference, Montreal, QC.

Rotter, J. B. (1966). Generalized expectancies for internal versus external control of reinforcement. Psychological Monographs: General and Applied, 8o(1), 1-28. 
Inter-subjective analysis of Engineering Leadership/ C. Rottmann, D. W. Reeve, R. Sacks, \& M. Klassen 172

Rottmann, C., Sacks, R., \& Reeve, D. W. (2015). Engineering leadership: Grounding leadership theory in engineers' professional identities. Leadership, 11(3), 351-373. doi:10.1177/1742715014543581

Schutz, A. (1967). The phenomenology of the social world. In C. Calhoun, J. Gerteis, J. Moody, S. Pfaff, \& I. Virk (Eds.), Contemporary sociological theory (pp. 32-41). Oxford, UK: Blackwell.

Shane, J., Strong, K., \& Gransberg, D. D. (2011). A multidimensional model of project leadership. Leadership and Management in Engineering, 11(2), 162-168.

Sheridan, P. K., Evans, G. J., \& Reeve, D. W. (2012, June). A proposed framework for teaching team-effectiveness in team-based projects. Paper presented at the American Society for Engineering Education Conference and Exposition, San Antonio, TX.

Sheridan, P. K., Reeve, D. W., \& Evans, G. J. (2012, June). Self- and peer-assessments of team-effectiveness in a first year engineering design course. Paper presented at the Canadian Engineering Education Association Conference, Winnipeg, MB.

Sheridan, P. K., Reeve, D. W., \& Evans, G. J. (2014, June). An on-line team-effectiveness learning system. Paper presented at the Canadian Engineering Education Association Conference, Canmore, AB.

Simpson, A. E., Evans, G. J., \& Reeve, D. W. (2010, June). A summer leadership development program for chemical engineering students. Paper presented at the Canadian Engineering Education Association Conference, Kingston, ON.

Singh, A., \& Jampel, G. (2011). Leadership flexibility space. Journal of Management in Engineering, 26(4), 176-188. doi:10.1061/(ASCE)ME.1943-5479.0000017

Skipper, C. O., \& Lansford, C. B. (2008). Leadership development and succession planning. Leadership and Management in Engineering, 8(2), 77-84. doi:10.1061/ (ASCE)1532-6748(2008)8:2(77)

Soundarajan, N., Ramnath, R., \& Weide, B. W. (2013, June). A multi-pronged approach to nurturing IT entrepreneurs. Paper presented at the 120th ASEE Annual Conference and Exposition, Atlanta, GA.

Stewart, G. B., III. (2005). The importance of economics. In National Academy of Engineering (Ed.), Educating the engineer of 2020: Adapting engineering education to the new century (pp. 156-159). Washington, DC: National Academies Press.

Toor, S. (2011). Differentiating leadership from management: An empirical investigation of leaders and managers. Leadership and Management in Engineering, 11(4), 310-320. doi:10.1061/(ASCE)LM.1943-5630.0000138

Toor, S., \& Ofori, G. (2011). Impact of aspirations and legacies of leaders in the construction industry in Singapore. Leadership and Management in Engineering, 11(1), 29-39. doi:10.1061/(ASCE)LM.1943-5630.0000098

Toor, S., \& Ogunlana, S. (2009). Ineffective leadership: Investigating the negative attributes of leaders and organizational neutralizers. Engineering, Construction and Architectural Management, 16(3), 254-272. doi:10.1108/09699980910951663 
Ulsoy, A. G. (2005, August). A 21st century engineering education for leading concurrent discovery and innovation. Paper presented at the CIRP (Collège International pour la Recherche en Productique) General Assembly, Antalya, Turkey. Retrieved from http://deepblue.lib.umich.edu/handle/2027.42/106409? show=full

Vest, C. M. (2005). Educating engineers for 2020 and beyond. In National Academy of Engineering (Ed.), Educating the engineer of 2020: Adapting engineering education to the new century (pp. 160-170). Washington, DC: National Academies Press.

Vest, C. M. (2011). The image problem for engineering: An overview. The Bridge, 41(2), 5-11.

Zhou, M., \& Liu, X. (2011, November). The understanding of the relationship between autonomy orientation and creativity: The moderating effect of authoritarian leadership. Paper presented at the International Conference on Information Management, Innovation Management and Industrial Engineering, Sanya, China.

\section{Contact Information}

Cindy Rottmann

Institute for Leadership Education in Engineering (ILead)

University of Toronto

cindy.rottmann@utoronto.ca

Cindy Rottmann is a senior research associate with the Institute for Leadership Education in Engineering (ILead) in the Faculty of Applied Science and Engineering, at the University of Toronto. Her research interests include engineering leadership, engineering education, engineering ethics, critical theory, teacher leadership, and social justice teacher unionism.

Douglas W. Reeve is a professor in the Department of Chemical Engineering and Applied Chemistry and founding director of the Institute for Leadership Education in Engineering (ILead) at the University of Toronto. His research interests are engineering leadership in the workplace and engineering leadership pedagogy.

Robin Sacks is an assistant professor in the Faculty of Applied Science and Engineering at the University of Toronto, where she teaches happiness, love, and play to future engineers. Her research interests include engineering leadership education, positive psychology, and identity development.

Mike Klassen is an assistant director, Community of Practice Engineering Leadership, Institute for Leadership Education in Engineering (ILead) in the Faculty of Applied Science and Engineering at the University of Toronto, where he develops leadership programs and industry partnerships for engineers. His research interests include engineering leadership, organizational culture, and higher education. 